\title{
Оценка фасоли зерновой по основным элементам продуктивности
}

Колупаев Д.А. *, аспирант; Якубенко О.Е., аспирантка; Паркина О.В., к.с.х.н., доиент

ФГБОУ ВО Новосибирский государственный аграрный университет, Новосибирск, Россия

*e-mail: kolupaevdenis@ngs.ru

Исследования проводились в 2018-2019 г2. на опытном поле УПХ «Сад Мичуринцев» Новосибирского ГАУ. Проведена комплексная оченка образиов фасоли обыкновенной зернового направления по основным элементам продуктивности. Выделены образиы, обладающие высокой урожайностью. Выявлены источники ценных признаков.

Ключевые слова: масса 1000 семян, урожайность, масса семян с растения, число семян в бобе, число семян с растения, фасоль обыкновенная.

\section{Assessment of grain beans by the main elements of productivity}

Kolupaev D. A., post-graduate student of the 1st year; Yakubenko O. E., postgraduate student of the 3rd year; Parkina O.V., Cand. associate Professor of agricultural SciencesNovosibirsk state agrarian University, Novosibirsk, Russia, kolupaevdenis@ngs.ru

The research was conducted in 2018-2019 at the experimental field of the EPF "Michurintsev Garden" of the Novosibirsk state UNIVERSITY. A comprehensive assessment of samples of common beans of the grain direction on the main elements of productivity was carried out. Samples with high yield were selected. Sources of valuable attributes are identified.

Key words: mass of 1000 seeds, yield, mass of seeds from a plant, number of seeds in a bean, number of seeds from a plant, common bean.

Фасоль обыкновенная относится к группе ценных высокобелковых продовольственных культур. По содержанию белка в семенах (от 17 до $32 \%$ ), жиров (от 2 до $3,5 \%$ ) и количеству незаменимых аминокислот превосходит пшеницу. В симбиозе с клубеньковыми бактериями растения фасоли фиксируют атмосферный азот и обогащают им почву, обеспечивая преимущество хорошего предшественника.

В настоящее время фасоль обыкновенная широко распространена в мировом земледелии, ее возделывают более чем в 70 странах в разных почвенно-климатических зонах. Выращивание фасоли в условиях сибирского региона ограничивается отсутствием сортов интенсивного типа и резким континентальным климатом, характеризующимся дефицитом теплообеспеченности в разные годы. В связи с этим актуально комплексное изучение 
лучших европейских и отечественных сортов и выделение источников хозяйственно-ценных признаков в условиях лесостепи Западной Сибири [1].

Цель исследования - комплексная оценка по основным элементам продуктивности.

Объект исследования - 25 образцов Phaseolus vulgaris L. зернового направления различного эколого-географического происхождения. Стандарт - районированный сорт Рубин (группа спелости - среднеранний).

Методика. Фенологические наблюдения проводили согласно методическим указаниям по изучению коллекции зерновых бобовых культур, морфологическое описание - по методическим указаниям по изучению образцов мировой коллекции фасоли $[2,3]$.

Посев в 2018-2019 гг. проводили по схеме 70×6 см, глубина заделки семян - 4 см. Норма высева - 23 шт./м². Площадь делянки $-2,1 \mathrm{~m}^{2}$.

Гидротермический режим вегетационного периода. Гидротермический режим 2018 года характеризовался поздним наступлением прогревания почвы (отклонение 1,5-2 недели) в силу дождливого (209 \% от нормы) и холодного мая (отклонение $4{ }^{\circ} \mathrm{C}$ ), что привело к смещению срока посева, и как следствие, к увеличению вегетационного периода. Это привело к тому, что созревание семян фасоли проходило на фоне пониженных температур, что не позволило в полной мере реализовать свой потенциал продуктивности.

Гидротермический режим 2019 года характеризовался благоприятными гидротермическими условиями для посева. Температурный режим был в пределах нормы, осадков немного больше нормы (117 \% от нормы). Своевременный срок посева семян обеспечивал благоприятные условия второй половины вегетационного периода: небольшое количество осадков (33 $\%$ от нормы) на фоне повышенных температур (отклонение $+2{ }^{\circ} \mathrm{C}$ ), что привело к дружному наступлению биологической спелости у всех образцов.

Результаты исследования. Проведена оценка образцов фасоли обыкновенной по урожайности и основным элементам продуктивности: число семян с растения, число семян в бобе, массе семян с растения, массе 1000 семян.

Таблица - Оценка фасоли обыкновенной по структуре урожая

\begin{tabular}{|c|c|c|c|c|c|c|}
\hline $\begin{array}{l}\text { № } \\
\Pi / \Pi\end{array}$ & Образец & $\begin{array}{c}\text { Число семян } \\
\text { с растения, } \\
\text { шт. }\end{array}$ & $\begin{array}{c}\text { Число } \\
\text { семян в } \\
\text { бобе, шт. }\end{array}$ & $\begin{array}{c}\text { Масса се- } \\
\text { мян с рас- } \\
\text { тений, Г }\end{array}$ & $\begin{array}{c}\text { Macca } \\
1000 \text { ce- } \\
\text { мян, Г }\end{array}$ & $\begin{array}{l}\text { Урожай- } \\
\text { ность, } \\
\text { Г/M² }\end{array}$ \\
\hline 1 & 2 & 3 & 4 & 5 & 6 & 7 \\
\hline 1 & Рубин, st & 34,1 & 3,7 & 14,5 & 433,3 & 264,8 \\
\hline 2 & Золотистая & 43,3 & 3,8 & 17,4 & 383,2 & 248,5 \\
\hline 3 & Пестрая & 32,7 & 3,9 & 12,6 & 400,7 & 191,8 \\
\hline 4 & Красно-пестрая & 23,9 & 4,4 & 11,9 & 535,7 & 243,3 \\
\hline 5 & Bomba & 31,1 & 3,7 & 9,0 & 305,0 & 152,8 \\
\hline 6 & Мотольская белая & 34,0 & 4,0 & 16,3 & 498,7 & 95,9 \\
\hline
\end{tabular}




\begin{tabular}{|c|c|c|c|c|c|c|}
\hline 1 & 2 & 3 & 4 & 5 & 6 & 7 \\
\hline 7 & Пестрая Романово & 25,7 & 3,7 & 11,4 & 463,5 & 205,2 \\
\hline 8 & Canario & 29,2 & 4,3 & 10,0 & 364,3 & 224,7 \\
\hline 9 & Stringless & 27,7 & 4,5 & 9,3 & 336,5 & 96,5 \\
\hline 10 & Мечта хозяйки & 35,9 & 4,9 & 14,7 & 424,3 & 154,5 \\
\hline 11 & Инга & 31,1 & 3,8 & 8,5 & 270,7 & 96,2 \\
\hline 12 & Бийчанка пестрая & 14,5 & 3,4 & 6,3 & 426,1 & 78,6 \\
\hline 13 & Красная шапочка & 17,7 & 2,5 & 10,7 & 527,1 & 82,8 \\
\hline 14 & Зуша белая & 31,6 & 3,7 & 18,1 & 541,0 & 67,9 \\
\hline 15 & Линия № 1 & 22,1 & 2,7 & 7,2 & 554,1 & 76,9 \\
\hline 16 & Veenoorl & 25,6 & 3,9 & 10,7 & 448,2 & 149,1 \\
\hline 17 & Мухранула & 19,5 & 4,1 & 9,5 & 522,9 & 181,9 \\
\hline 18 & Katia & 38,3 & 3,4 & 14,5 & 403,7 & 148,8 \\
\hline 19 & Нерусса & 78,6 & 4,0 & 15,4 & 201,1 & 196,5 \\
\hline 20 & Зуша черная & 59,7 & 3,6 & 15,0 & 253,0 & 280,3 \\
\hline 21 & Лукерья & 53,2 & 3,9 & 17,3 & 370,1 & 264,4 \\
\hline 22 & Creola & 41,6 & 4,0 & 22,4 & 293,3 & 222,9 \\
\hline 23 & Brunot & 26,3 & 4,4 & 9,3 & 326,1 & 140,5 \\
\hline 24 & Зуша пестрая & 21,2 & 3,3 & 13,5 & 684,1 & 94,5 \\
\hline 25 & Оран & 49,2 & 3,5 & 11,5 & 249,5 & 125,1 \\
\hline \multicolumn{2}{|c|}{ Lim } & $14,5 \div 78,6$ & $2,5 \div 4,9$ & $6,3 \div 22,4$ & $201,1 \div 684,1$ & $67,9 \div 280,3$ \\
\hline \multicolumn{2}{|r|}{$\overline{\mathrm{X}}$} & 33,912 & 3,804 & 12,68 & \begin{tabular}{|l|}
408,648 \\
\end{tabular} & \begin{tabular}{|l|}
163,376 \\
\end{tabular} \\
\hline \multicolumn{2}{|r|}{$\delta$} & 14,382 & 0,522 & 3,863 & 116,105 & 67,777 \\
\hline \multicolumn{2}{|r|}{$\mathrm{Cv}, \%$} & $42 \%$ & $14 \%$ & $30 \%$ & $28 \%$ & $41 \%$ \\
\hline
\end{tabular}

Число семян с растения изменялось от минимального усредненного значения у сорта Бийчанка пестрая, равное 15 шт. до максимального усредненного значения 79 шт. у сорта Нерусса. Среднее значение признака составило 34 шт., что на уровне стандарта. Стандартное отклонение по сортам, равно 14,382, коэффициент вариации $42 \%$.

По числу семян в бобе можно выделить образцы с максимально выраженным усредненным значением признака у сортов Мечта хозяйки, Stringless - 5 шт. Наименьшее число завязавшихся семян в бобе отмечено у сорта Красная шапочка и образца Линия № $1-3$ шт. Среднее значение признака составило 4 шт., что является на уровне стандарта. Стандартное отклонение составило 0,522 с коэффициентом вариации, равным 14 \%.

Масса семян с растения имела широкий разброс средних значений от 6,3 г у сорта Бийчанка пестрая до 22,4 г у сорта Creola. Среднее значение признака по образцам составило 12,7 г, что меньше стандарта на 1,8 г. Стандартное отклонение составило 3,863 с коэффициентом вариации, равным 30 \%.

Усредненная масса 1000 семян варьировала от 201,1 г у сорта Нерусса до 684,1 г у сорта Зуша пестрая. Среднее значение признака по изучаемым образцам составило 408,6 г, что меньше стандарта на 24,7 г. Стандартное отклонение составило 116,1 г. Коэффициент вариации равен 28 \%. 
Максимальной усредненной урожайностью обладал сорт Зуша черная, равной 280,3 г; минимальная урожайность, равная 67,9 г выявлена у сорта Зуша белая. Средняя урожайность по образцам составила 163,4 г/м², что меньше стандарта 1,62 раза. Стандартное отклонение составило 67,777 с коэффициентом вариации, равным $41 \%$.

Заключение. В ходе изучения образцов фасоли обыкновенной зернового направления с целью повышения продуктивности были выделены образцы-источники хозяйственно-ценных признаков:

- число семян в бобе: Красно-пестрая, Stringless, Мечта хозяйки, Brunot;

- число семян с растения: сорта Нерусса и Зуша черная;

- масса 1000 семян (с учетом оптимальной массы 1000 семян для механизированного возделывания): Золотистая, Пестрая, Bomba, Пестрая Романово, Canario, Stringless, Мечта хозяйки, Бийчанка пестрая, Veenoorl, Katia, Лукерья, Brunot.

По комплексу хозяйственно-ценных признаков выделился образец Красно-пестрая.

\section{Список литературы}

1. Маракаева Т.В. Сравнительная оценка хозяйственно-ценных признаков фасоли (Phaseolus vulgaris L.) и создание на их основе нового селекционного материала для условий южной лесостепи Западной Сибири: Дис. ... канд. с.-х. наук. - Омск, 2014. $180 \mathrm{c}$.

2. Методические указания по изучению коллекции зерновых бобовых культур. Санкт-Петербург, 1975. - 60 с.

3. Методические указания. Методика проведения испытаний на отличимость, однородность и стабильность (Фасоль обыкновенная Phaseolus vulgaris L.). - М.: 1995. $-14 \mathrm{c}$.

DOI $10.18699 / \mathrm{GPB} 2020-38$

\section{Влияние полиморфных вариантов CAD (EC 1.1.1.195) на устойчивость пшеницы к грибным инфекциям}

Коновалов А.А. ${ }^{1 *}$, д.б.н., с.н.с.; Орлова Е.А. ${ }^{2}$, к.с-х.н., в.н.с.; Карпова Е.В. ${ }^{3}$, к.х.н., с.н.с.; Шундрина И.К. ${ }^{3}$, к.х.н., с.н.с.

${ }^{1}$ Федеральный исследовательский центр Институт ичитологии и генетики Сибирского отделения Российской академии наук, Новосибирск, Россия;

${ }^{2}$ Сибирский научно-исследовательский институт растениеводства и селекиии - филиал ИЦиГ СО РАН, пос. Краснообск, Россия;

${ }^{3}$ Новосибирский институт органической химии им. Н.Н. Ворожиова Сибирского отделения Российской академии наук, Новосибирск, Россия.

*e-mail:konov@bionet.nsc.ru 